\title{
Pendampingan Penguatan Kompetensi Guru dan Siswa SMA Melalui Pengembangan Inovasi Sains dan Kompetisi Olimpiade Biologi di Kabupaten Sampang, Madura
}

\section{Eko Suyanto, Anna Safitri, Nia Kurnianingsih, Fatchiyah Fatchiyah}

Pusat Studi Molekul Cerdas Berbasis Sumber Genetik Alami (SMONAGENES),Universitas Brawijaya, Malang, Indonesia

E-mail: fatchiya@ub.ac.id

\section{Article History:}

Received: Aug 6 th $^{2020}$

Revised: Sept 30th 2020

Accepted: Nov 30th

Keywords: educational quality, community-based research, innovation, competition.

\begin{abstract}
Teachers and students need more knowledge to improve their competence. The educational quality can be improved by varying learning methods and supported by competition. This community service activity aims to strengthen the competence of teachers and students through learning innovation in the Biology subject and to provide learning competition of Biology Olympiad through simulation and training. The communitybased research (CBR) method was performed by workshop and training involving 60 participants. As many as $100 \%$ of the participants attended the activities. The results indicated that the participants acquired new knowledge and realized their competence skills. Learning innovation and competition were able to improve their knowledge and competence. The participants are eager to apply the methods learned at school. These new competence and skill are expected to improve the quality of education.
\end{abstract}

\section{Pendahuluan}

Kabupaten Sampang, Madura pernah masuk ke dalam kawasan dengan kategori daerah tertinggal berdasarkan Perpres No 131 Tahun 2015 tentang penetapan daerah tertinggal tahun 2015-2019. Salah satu kriteria penilaian yang menyebabkan kabupaten Sampang mendapatkan kategori ini adalah sumber daya manusia yang dimiliki dimana Indeks Pembangunan Manusia (IPM) kabupaten Sampang menduduki peringkat bawah dibandingkan dengan daerah lain di wilayah provinsi Jawa Timur. Nilai IPM kabupaten Sampang berada pada kategori 'sedang' dengan nilai 59,90\% pada tahun 2017 namun nilainya paling rendah dibandingkan kabupaten lain di pulau Madura'. Saat ini kabupaten

1 Yani Arthayanti, I Gusti Ayu Made Srinadi, and G.K. Gandhiadi, “Geographically Weighted Ridge Regression Dalam Kasus Multikolinearitas Pada Indeks Pembangunan Manusia Di Kabupaten/Kota Provinsi Jawa Timur," Jurnal Matematika 7, no. 2 (2017): 124-131; Indah Purnama Sari, Bado Riyono, and 
Sampang tidak termasuk wilayah tertinggal berdasarkan Perpres No. 63 tahun 2020 tentang penetapan daerah tertinggal tahun 2020-2024 namun nilai IPM kabupaten Sampang hanya sebesar $61,94 \%$ sehingga pada tahun ini kembali menduduki peringkat terendah di provinsi Jawa Timur².

Nilai ini menunjukkan kualitas atau kemampuan wilayah pada tiga dimensi dasar yaitu pendidikan, kesehatan dan standar hidup layak. Selain itu, IPM juga menunjukkan ukuran kemampuan pembangunan wilayah pada kualitas fisik yaitu angka harapan hidup dan non fisik penduduk yaitu rerata pendidikan penduduk dan angka melek huruf3. Rerata taraf ekonomi penduduk, akses dan fasilitas pendidikan yang dimiliki kabupaten Sampang juga masih minim sehingga mayoritas anak usia sekolah menghadapi permasalahan besar yaitu kurangnya minat dan semangat belajar serta lebih mengutamakan bekerja daripada melanjutkan sekolah yang berdampak pada angka putus sekolah di wilayah tersebut meningkat ${ }^{4}$.

Kenyataan umum tentang masalah pendidikan di daerah ini berkorelasi linear dengan kualitas pendidikan di sekolah dan menjadi salah satu alasan yang menyebabkan rerata nilai ujian nasional yang diperoleh siswa Sekolah Menengah Atas (SMA) di kabupaten Sampang berada pada peringkat bawah di provinsi Jawa Timur. Rendahnya nilai nasional siswa SMA juga diikuti dengan minimnya prestasi guru dan siswa pada kompetisi olimpiade sains nasional. Hal ini juga menjadi masalah utama bagi guru serta instansi terkait untuk mengembangkan berbagai strategi pendidikan guna meningkatkan daya pikir dan pemahaman siswa terhadap pelajaran yang diberikan.

Masalah ini merupakan cerminan dari mutu pendidikan di sekolah yang juga menjadi permasalahan yang dihadapi oleh guru termasuk guru biologi SMA. Berdasarkan wawancara dan diskusi dengan tim Musyawarah Guru Mata Pelajaran (MGMP) biologi kabupaten Sampang bahwa guru dan siswa menghadapi beberapa permasalahan antara lain siswa SMA masih sering mengalami kesulitan dalam memahami pelajaran ilmu biologi. Hal ini didukung dengan kajian sebelumnya yang melaporkan bahwa hasil belajar siswa pada pelajaran ini masih menunjukkan hasil yang belum memuaskan5. Kesulitan yang dialami disebabkan karena metode pembelajaran yang diberikan dan minimnya semangat untuk berkompetisi dalam meningkatkan pemahaman. Di sisi lain, guru

Agus Supandi, "Indeks Pembangunan Manusia Di Madura: Analisis Tipologi Klassen," Journal of Applied Business and Economics 6, no. 2 (2019): 82-95.

2 Badan Pusat Statistik, Jawa Timur Dalam Angka 2020 (Surabaya: BPS Surabaya, Jawa Timur, 2020).

${ }^{3}$ Eka Pratiwi Lumbantorum and Paidi Hidayat, "Analisis Pertumbuhan Ekonomi Dan Indeks Pembangunan Manusia (IPM) Provinsi-Provinsi Di Indonesia (Metode Kointegrasi)," Jurnal Ekonomi dan Keuangan 2, no. 2 (2014): 14-27.

${ }^{4}$ Syamsul Arifin, "Kemitraan Sekolah-Masyarakat Sebagai Upaya Peningkatan Mutu Pendidikan Di Sampang, Jawa Timur," Jurnal Humanity 8, no. 1 (2012): 203-219.

${ }^{5}$ Syaiful Rohman, "Penerapan Model Pembelajaran Kooperatif Tipe CIRC Untuk Meningkatkan Hasil Belajar Konsep Metabolisme Dan Respon Peserta Didik Kelas XII IPA-7 SMA Negeri 1 Sampang Tahun Pelajaran 2011/2012," Jurnal Pena Sains 2, no. 1 (2015): 7-13. 
sebagai pendidik juga sangat membutuhkan penguatan kompetensi dan pengetahuan serta masih mengalami kesulitan dalam melakukan inovasi pembelajaran karena tuntutan pekerjaan administrasi yang membutuhkan waktu dan tenaga lebih banyak sehingga pengembangan inovasi metode pembelajaran sedikit terabaikan. Selain itu, metode pembelajaran biologi selama ini cenderung masih berpusat pada guru sehingga tidak efektif dan tidak efisien karena kurang melibatkan siswa dalam pengembangan motivasi, kemampuan berpikir kritis, dan bertindak ${ }^{6}$.

Metode pembelajaran adalah alat dan teknik yang digunakan sebagai perantara komunikasi guru dan murid dalam proses pendidikan di sekolah agar siswa dapat menguasai bidang ilmu yang dipelajari ${ }^{7}$. Hal ini menjadi penting karena pembelajaran biologi memerlukan kemampuan memahami, memecahkan masalah, dan pengalaman terlibat secara langsung ${ }^{8}$. Oleh karena itu, guru perlu meningkatkan pengetahuan dan kompetensi sebagai upaya peningkatan kualitas ilmu pengetahuan yang dimiliki serta berupaya meningkatkan kualitas metode pembelajaran menggunakan berbagai media pembelajaran secara terus menerus sehingga memudahkan siswa untuk memahami pelajaran yang diberikan9. Hal ini menjadi bagian dari kompetensi yang harus dimiliki oleh guru meliputi kompetensi pedagogik, kepribadian, sosial dan profesional sehingga dapat membantu siswa dalam mencapai kompetensi dasar yang diharapkan.

Selain itu, penguatan kompetensi profesional guru dan kompetensi siswa dapat dilakukan dengan kegiatan kompetisi. Kompetisi menjadi salah satu sarana dalam pengembangan kompetensi dan profesionalitas guru sehingga membantu guru dalam mempersiapkan manusia cerdas intelektual, berkarakter, berdaya saing dan kompetitif ${ }^{\circ}$. Kompetisi juga dapat memacu peningkatan kompetensi siswa baik di bidang sains, teknologi dan matematika sehingga siswa mampu menguasai ilmu pengetahuan dengan baik, mampu mengembangkan bakat dan minat serta menjadi bagian dalam upaya

${ }^{6}$ Listiana, "Realitas Pengembangan Keterampilan Berpikir Dalam Pembelajaran Biologi: Studi Pendahuluan Di SMA Muhammadiyah Se-Surabaya," in Prosiding Seminar Nasional Dan Workshop Nasional Biologi/IPA Dan Pembelajarannya (Malang: FMIPA Jurusan Biologi Universitas Negeri Malang, 2014), 340347; Rohman, "Penerapan Model Pembelajaran Kooperatif Tipe CIRC Untuk Meningkatkan Hasil Belajar Konsep Metabolisme Dan Respon Peserta Didik Kelas XII IPA-7 SMA Negeri 1 Sampang Tahun Pelajaran 2011/2012."

7 Sudjana and Rivai, Media Pengajaran (Bandung: Sinar Baru Algensido, 2010); Rangga Sa'adillah S.A.P. et al., "Dampak Pendekatan Saintifik Terhadap Sikap Spiritual Siswa Dalam Pembelajaran PAI Di SMA Di Sidoarjo," Jurnal Pendidikan Agama Islam (Journal of Islamic Education Studies) 7, no. 2 (2019): 143-165.

8 Listiana, "Realitas Pengembangan Keterampilan Berpikir Dalam Pembelajaran Biologi: Studi Pendahuluan Di SMA Muhammadiyah Se-Surabaya."

${ }^{9}$ Slameto, Belajar Dan Faktor-Faktor Yang Mempengaruhi (Jakarta: Rineka Cipta, 2010).

10 Kementerian Pendidikan dan Kebudayaan, Pedoman Pelaksanaan Olimpiade Guru Nasional (OGN) Pendidikan Menengah Dan Pendidikan Khusus. (Jakarta: Direktorat Pembinaan Guru Pendidikan Menengah dan Pendidikan Khusus, 2019). 
pemerataan pendidikan". Salah satu kompetisi tersebut adalah olimpiade sains yang meliputi Olimpiade Sains Nasional (OSN) dan Olimpiade Guru Nasional (OGN) ${ }^{12}$.

Olimpiade Sains Nasional (OSN) adalah kegiatan kompetisi sains antar peserta didik yang rutin dilaksanakan setiap tahun oleh pemerintah sejak tahun 2002 dengan harapan dapat menjaga dan meningkatkan mutu pendidikan ${ }^{13}$. Selain berupaya meningkatkan kualitas siswa, pemerintah juga memacu kualitas guru dengan mengadakan Olimpiade Guru Nasional (OGN). Salah satu bidang yang dikompetisikan dalam olimpiade tersebut adalah bidang biologi. Olimpiade biologi diselenggarakan melalui serangkaian proses seleksi secara berjenjang dari tingkat antar sekolah hingga ke tingkat internasional. Partisipasi pada olimpiade menjadi sarana yang baik bagi guru dan siswa untuk aktualisasi diri dalam mencintai ilmu dan teknologi, pengembangan kemampuan diri serta sebagai upaya untuk meningkatkan kualitas pendidikan. Secara umum, mutu pendidikan dapat ditingkatkan melalui kurikulum pendidikan, metode pembelajaran yang tepat dan didorong oleh kompetisi sehingga kompetisi bukan menjadi tujuan utama melainkan hanya salah satu sarana untuk mencapai tujuan tersebut ${ }^{14}$.

Pembelajaran merupakan proses komunikasi efektif dan interaktif antar peserta didik dengan pendidik serta antar peserta didik menggunakan sumber atau media belajar pada suatu lingkungan belajar ${ }^{15}$. Media pembelajaran berfungsi sebagai sarana untuk memperjelas sesuatu yang rumit dari penyajian pesan dan informasi sehingga dapat memperlancar serta meningkatkan hasil proses belajar mengajar. Terdapat berbagai macam media pembelajaran yang dapat digunakan oleh pendidik dalam meningkatkan minat belajar dan pemahaman siswa tentang biologi seperti penggunaan media power point, audio visual, video dan praktikum. Pembelajaran melalui praktikum menjadi salah satu sarana yang dirasa lebih baik karena melibatkan aspek melihat, mendengar dan

11 Kementerian Pendidikan dan Kebudayaan, Pedoman Olimpiade Sains Nasional Tahun 2019 (Jakarta: Direktorat Jenderal Pendidikan Dasar dan Menengah, 2019).

12 Aris Doyan et al., "Pelatihan Olimpiade MIPA Bagi Guru Dan Peserta Didik SMA Kesuma Mataram," Jurnal Pengabdian Magister Pendidikan IPA 1, no. 1 (2018): 20-23; Muhammad Erfan et al., "Pendampingan Persiapan Olimpiade Sains Nasional (OSN) Tingkat Kabupaten Bagi Siswa SMA Negeri 4 Sumbawa," Jurnal Pendidikan dan Pengabdian Masyarakat 2, no. 1 (2019): 114-119.

13 Fitra Muliani, Dewi Noviati, and Fajriani, "Pembinaan Peningkatan Mutu Pendidikan Bidang Olimpiade Sains Bagi Guru SD Kota Langsa Provinsi Aceh," Jurnal Pengabdian Masyarakat Universitas Merdeka Malang 3, no. 2 (2018): 9-13.

14 Tri Wiyoko et al., "Peningkatan Kompetensi Siswa Melalui Pembinaan Olimpiade Sains (OSN)," Warta LPM 22, no. 2 (2019): 67-75; Kementerian Pendidikan dan Kebudayaan, Pedoman Pelaksanaan Olimpiade Guru Nasional (OGN) Pendidikan Menengah Dan Pendidikan Khusus.; Kementerian Pendidikan dan Kebudayaan, Pedoman Olimpiade Sains Nasional Tahun 2019.

15 Abdul Majid, Perencanaan Pembelajaran : Mengembangkan Standar Kompetensi Guru (Bandung: PT Remaja Rosdakarya, 2013); Rangga Sa'adillah Sandhy Atma Putra, "Pembelajaran Pendidikan Agama Islam Melalui Pendekatan Saintifik Dalam Membentuk Sikap Spiritual Siswa Sekolah Menengah Atas Di Sidoarjo (Studi Fenomenologi Pengalaman Guru Dan Siswa Pada SMA Di Sidoarjo)" (Universitas Muhammadiyah Malang, 2020), http://eprints.umm.ac.id/65683/; Muh Barid Nizarudin Wajdi et al., "Pendampingan Redesign Pembelajaran Masa Pandemi Covid-19 Bagi Tenaga Pendidik Di Lembaga Pendidikan Berbasis Pesantren Di Jawa Timur," Engagement: Jurnal Pengabdian Kepada Masyarakat 4, no. 1 (2020): 266-277. 
psikomotorik dalam satu waktu' ${ }^{16}$ Namun, berdasarkan hasil diskusi dengan guru menunjukkan bahwa kegiatan praktikum dengan jumlah yang banyak masih dirasakan sulit diterapkan karena memerlukan biaya yang cukup besar.

Berdasarkan semua permasalahan yang disebutkan diatas, tim pengabdi perlu melakukan pendampingan untuk meningkatkan kompetensi guru dan siswa melalui pengembangan pembelajaran inovasi sains dan kompetisi olimpiade biologi sehingga diharapkan nantinya kegiatan ini menjadi stimulus gerakan perubahan dan kesadaran bagi pengambil kebijakan untuk menerapkan metode pembelajaran yang murah, inovatif dan kreatif demi terwujudnya sumber daya manusia yang berkualitas dan berdaya saing serta berpotensi meningkatkan prestasi guru dan siswa di olimpiade sains melalui terbentuknya berbagai forum dan kompetisi olimpiade. Tujuan kegiatan pengabdian masyarakat ini adalah untuk melakukan pendampingan penguatan kompetensi guru dan siswa serta membekali kemampuan kompetisi olimpiade sains biologi bagi guru dan siswa SMA. Kegiatan pengabdian ini menjadi penting untuk menjembatani sekaligus menjadi solusi bagi permasalahan yang dihadapi guru biologi dan siswa di Kabupaten Sampang.

\section{Metode}

Kegiatan pengabdian masyarakat dilaksanakan di Balai Latihan Kerja, Kabupaten Sampang, Madura. Pihak yang terlibat yaitu Dinas Pendidikan Kabupaten Sampang, ketua MGMP biologi Kabupaten Sampang beserta guru biologi SMA dan siswa SMA negeri maupun swasta yang terhimpun dalam komunitas tersebut. Metode yang digunakan dalam kegiatan pengabdian masyarakat ini menerapkan metode community based research (CBR) melalui pendekatan secara langsung disertai dengan conceptual learning dan procedural fluency sehingga terjadi proses transfer pengetahuan antar tim pengabdi (peneliti) dan komunitas (mitra) ${ }^{17}$. Proses ini sangat penting guna menjaga momentum dalam mencapai perubahan yang diharapkan karena adanya proses saling kerjasama antar pihak $^{18}$. Metode pendekatan ini dilakukan karena memungkinkan menerapkan keterpaduan Tridharma sekaligus yaitu pendidikan, penelitian dan pengabdian ${ }^{19}$. Metode CBR merupakan salah satu metode kajian riset berbasis komunitas yang berupaya memberikan dukungan, daya serta keterlibatan aktif komunitas dalam proses pemberdayaan untuk menghasilkan sesuatu nilai yang bermanfaat bagi komunitas ${ }^{20}$.

${ }^{16}$ A Arsyad, Media Pembelajaran (Jakarta: Rajawali Press, 2011).

17 Tim Penyusun Panduan CBR UIN Sunan Surabaya, Community Based Research: Sebuah Pengantar (Surabaya: SILE/LLD, 2015).

18 Karen Hacker et al, "Community Capacity Building and Sustainability: Outcomes of CommunityBased Participatory Research," Prog. Community Health Partnership 6, no. 3 (2012): 349-360.

19 Moh Hafiyusholeh et al., "Pendampingan Guru Madrasah Untuk Mewujudkan Kompetensi Pedagogik Guru Matematika Yang Berdaya Melalui Penguasaan Soal High Order Thinking Skills (HOTS),” Engagement: Jurnal Pengabdian Kepada Masyarakat 4, no. 1 (2020): 183-200.

20 Sarah Banks and Paul Manners, Community-Based Participatory Research: A Guide to Ethical 
Metode ini memperhatikan identifikasi masalah yang dihadapi, identifikasi prioritas dukungan, identifikasi pengembangan program dan menjawab kebutuhan masyarakat. Tahapan metode terdiri dari beberapa aspek yaitu peletakan dasar llaying the foundation), perencanaan penelitian (research planning), pengumpulan dan analisis data (information gathering and analysis) dan aksi temuan (acting on findings) ${ }^{21}$.

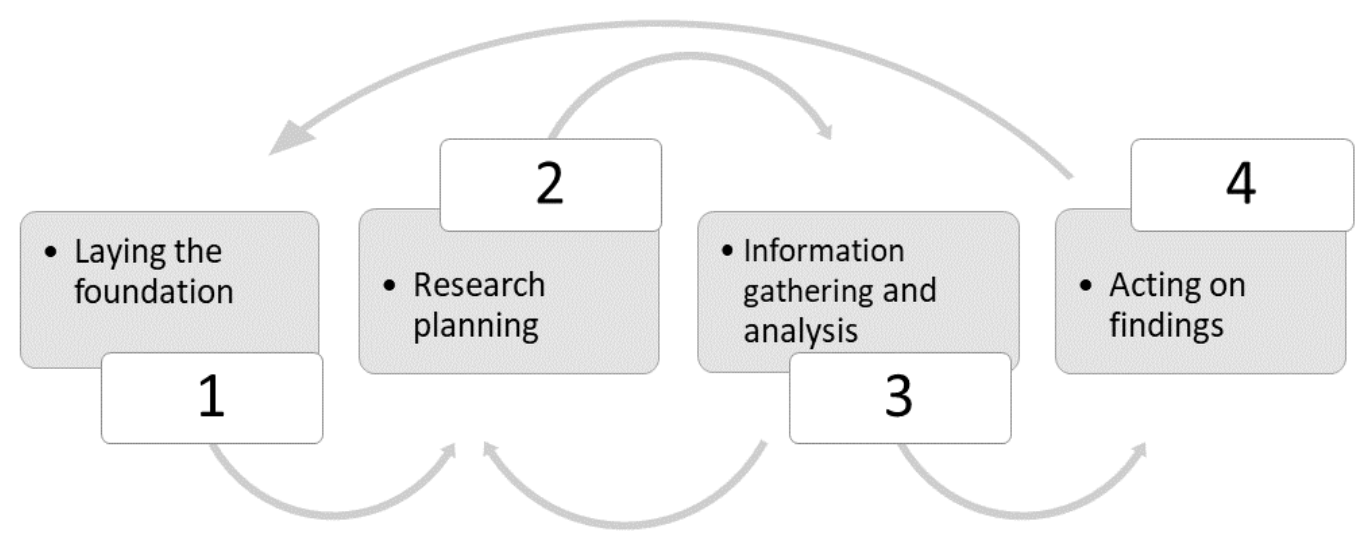

Gambar 1. Tahapan metode dalam $\mathrm{CBR}^{22}$

Secara lengkap, metode dalam kegiatan pengabdian masyarakat ini terdiri dari beberapa tahapan kegiatan sebagai berikut,

Peletakan dasar (laying foundation). Pada tahapan ini tim pengabdi melakukan studi pendahuluan melalui berbagai sumber informasi di internet untuk mengetahui kondisi mitra komunitas yang dituju yaitu guru biologi SMA dan siswa SMA negeri maupun swasta yang terhimpun dalam komunitas MGMP biologi, kabupaten Sampang

Principles and Practice (Durham, UK: Center for Social Justice and Community Action, Durham University, 2012).

${ }^{21}$ Martin Mulligan and Yaso Nadarajah, "Working on the Sustainability of Local Communities with a 'Community-Engaged' Research Methodology," Local Environment 13, no. 2 (2008): 81-94.

${ }^{22}$ Abdul Muhid et al., "Perubahan Perilaku Open Defecation Free ( ODF) Melalui Program Sanitasi Total Berbasis Masyarakat ( STBM ) Di Desa Babad," Engagement; Jurnal Pengabdian Kepada Masyarakat 2, no. 1 (2018): 99-119. 
(Tabel 1). Selain itu juga dilakukan kegiatan korespondensi, wawancara dan Focus Group Discussion (FGD) dengan guru biologi yang terhimpun dalam MGMP biologi kabupaten Sampang, Madura untuk mendapatkan profil tentang guru dan siswa, profil MGMP dan gambaran secara utuh mengenai permasalahan yang dihadapi oleh mitra (identifikasi masalah), pemetaan kondisi mitra, tujuan dan urgensi kegiatan, kebutuhan mitra dan penentuan target akhir dari pendampingan. Melalui kegiatan ini tim pengabdi mendapatkan data dan pengetahuan yang digunakan sebagai bahan koordinasi pada rapat tim pengabdi untuk mengkaji informasi yang diperoleh sehingga mendapatkan solusi atas permasalahan yang dihadapi serta menentukan prioritas program kegiatan pengabdian yang tepat untuk menjawab kebutuhan mitra. Selain itu juga merumuskan kompetensi masing-masing tim pengabdi dan membangun persepsi yang sama dalam melaksanakan pengabdian masyarakat agar mendapatkan hasil yang optimal. Pada tahapan ini dilakukan menggunakan pendekatan partisipatif yaitu melibatkan guru dan siswa secara aktif. Mitra memberikan respon yang positif pada tahapan kegiatan ini dan sangat antusias untuk terlibat secara aktif dalam kegiatan.

Tabel 1. Daftar peserta kegiatan pengabdian masyarakat.

\begin{tabular}{clccc}
\hline No & \multicolumn{1}{c}{ Nama sekolah } & Jumlah siswa & Jumlah guru & Total \\
\hline 1 & SMAN 1 Sampang & 5 & 4 & 9 \\
\hline 2 & SMAN 2 Sampang & 5 & 3 & 8 \\
\hline 3 & SMAN 3 Sampang & 4 & 3 & 7 \\
\hline 4 & SMAN 4 Sampang & 3 & 2 & 5 \\
\hline 5 & SMAN 1 Torjun & 4 & 3 & 7 \\
\hline 6 & SMAN 1 Kedungdung & 4 & 2 & 6 \\
\hline 7 & SMAN 1 Ketapang & 2 & 2 & 4 \\
\hline 8 & SMA Darussyahid & 1 & 2 & 3 \\
\hline 9 & SMA Khairul Ulum & 1 & 1 & 2 \\
\hline 10 & SMA Robatal & 1 & 0 & 3 \\
\hline 11 & SMAN 1 Sreseh & 0 & 3 & 2 \\
\hline 12 & SMAN 1 Banyuates & 0 & 2 & 2 \\
\hline 13 & SMAS Arrohmaniyah & 0 & 1 & 60 \\
\hline 14 & SMA Nazhatut Thullab & 0 & 2 & \\
\hline & & 30 & 30 & \\
\hline
\end{tabular}

Perencanaan penelitian (research planning). Setelah tim pengabdian masyarakat melakukan kajian dari informasi yang diperoleh maka pada tahapan ini tim pengabdi menentukan kegiatan pengabdian yang dibutuhkan oleh mitra. Tim melakukan rapat persiapan kegiatan pengabdian dan koordinasi dengan mitra untuk mendapatkan kesepakatan tentang desain kegiatan yang akan dilakukan agar menjadi solusi atas permasalahan yang dihadapi, menentukan pembicara untuk setiap kegiatan serta menyiapkan bahan dan alat yang dibutuhkan selama kegiatan berlangsung serta mengkoordinasi peserta kegiatan (Tabel 1). Dalam perencanaan ini mitra terlibat aktif 
dalam rencana kegiatan dan melakukan koordinasi internal serta menggerakkan anggota komunitas dan siswa SMA untuk terlibat dalam kegiatan. Selain itu, mitra juga terlibat dalam perencanaan beberapa bahan yang digunakan selama kegiatan berlangsung. Dengan memperhatikan berbagai aspek maka disepakati kegiatan pendampingan berupa workshop yang menerapkan pendekatan active based learning yaitu melibatkan secara aktif peserta dalam kegiatan pengabdian sehingga diharapkan akan menghasilkan sesuatu yang bermanfaat bagi guru dan siswa. Kegiatan workshop ini terdiri dari sosialisasi (conceptual learning) serta simulasi dan pelatihan (procedural fluency). Sosialisasi konsep biologi dan sains dilaksanakan dengan mengadakan ceramah dan diskusi. Sosialisasi melalui ceramah terdiri dari 3 sesi dengan tujuan untuk memberikan penguatan pemahaman konsep biologi kepada guru dan siswa tentang materi biologi sel dan molekuler, aplikasi sains dalam pembelajaran olimpiade sains serta pembinaan dan penguatan materi olimpiade sains nasional bidang biologi. Setiap sesi menyediakan waktu untuk diskusi sehingga pada sosialisasi ini memberikan kesempatan peserta untuk aktif terlibat.

Kegiatan simulasi dan pelatihan merupakan kelanjutan dari tahap sosialisasi sebelumnya yang bertujuan untuk menguatkan konsep yang diperoleh sehingga dapat memberikan pemahaman yang lebih baik kepada mitra. Kegiatan ini dilakukan dengan menggunakan metode simulasi dan pelatihan yang terdiri dari pelatihan teknik isolasi DNA organisme, pelatihan sains pembuatan teknologi sederhana serta simulasi kompetisi olimpiade sains nasional bidang biologi dan pembahasan soal. Soal kompetisi olimpiade sains nasional bidang biologi dibuat oleh tim pengabdi dan telah disetarakan dengan level soal olimpiade sains nasional. Kegiatan ini bertujuan untuk mengetahui tingkat pemahaman dasar guru dan siswa pada bidang yang sama serta memberikan pembelajaran kompetisi kepada guru dan siswa sehingga hasil kompetisi akan menggambarkan sejauh mana pemahaman dan kemampuan dasar guru dan siswa dalam mengerjakan soal level olimpiade biologi. Peserta dengan nilai terbaik mendapatkan penghargaan berupa buku biologi molekuler yang ditulis oleh tim pengabdi dan produk NUTRILUX, yaitu produk hasil penelitian oleh pengabdi berupa produk kosmetika. Setelah kegiatan selesai, dilakukan diskusi evaluatif antar pengabdi dan mitra.

Pengumpulan dan analisis data (information gathering and analysis). Teknik pengumpulan data dilakukan dengan melibatkan mitra melalui pengisian kuesioner oleh guru dan siswa untuk mendapatkan umpan balik dari mitra selama kegiatan berlangsung. Mitra terlibat aktif dalam memberikan penilaian kegiatan dan memberikan saran sehingga mitra juga dapat melakukan analisis dan interpretasi data bersama. Keberhasilan dapat dilihat dari kehadiran dan aktivitas mitra selama kegiatan serta hasil analisis kuesioner menggunakan teknik scoring. Kegiatan dinyatakan berhasil bilamana dihadiri dan diikuti secara penuh oleh lebih dari 90\% peserta serta peserta mendapatkan manfaat peningkatan pemahaman dan wawasan dari kegiatan ini. Selain itu juga dilakukan evaluasi penilaian penguasaan materi olimpiade biologi menggunakan skala 
nilai berdasarkan analisis nilai pada lembar jawaban soal olimpiade dari guru dan siswa.

Aksi temuan (acting on findings). Pada tahapan ini merupakan aksi berupa mobilisasi pengetahuan tentang temuan yang ada. Tim pengabdi dan mitra melakukan FGD singkat dengan mitra setelah kegiatan berlangsung untuk mengkaji temuan yang ada dan merumuskan ide gagasan yang bisa diterapkan untuk meningkatkan kompetensi. Selain itu, tim pengabdi juga memberikan ide dan gagasan kegiatan yang bisa diterapkan dalam program kerja MGMP biologi maupun diterapkan dalam proses pembelajaran biologi di sekolah sehingga diharapkan memacu peningkatan mutu pendidikan.

\section{Hasil}

Tim mengawali kegiatan dengan melakukan kajian mengenai kondisi dan permasalahan yang dihadapi oleh dunia pendidikan di kabupaten Sampang secara umum dan khususnya pada pendidikan biologi di SMA melalui studi literatur, korespondensi, wawancara partisipatif dan FGD yang melibatkan guru SMA dalam komunitas MGMP biologi kabupaten Sampang sehingga tim pengabdian masyarakat mendapatkan pengetahuan mengenai permasalahan yang dihadapi sebagai bagian dari identifikasi masalah. Keterlibatan guru dalam FGD juga bertujuan partisipatif dan konstributif untuk memberikan saran serta diskusi dalam penyelesaian masalah dengan harapan bahwa solusi yang diberikan nantinya dapat diimplementasikan dalam kebijakan pendidikan selama proses belajar mengajar sehingga mampu meningkatkan mutu pendidikan.

Berdasarkan hasil identifikasi masalah diperoleh informasi bahwa permasalahan umum yang dihadapi yaitu banyaknya ketidakpuasan dari masyarakat terhadap kualitas pendidikan, disparitas lembaga pendidikan di perkotaan dan pedesaan baik dari kualitas guru, rasio guru dengan murid, fasilitas pendidikan, maupun akses pendidikan serta rendahnya partisipasi masyarakat terhadap pendidikan. Permasalahan khusus yang dihadapi oleh mitra meliputi rendahnya minat belajar siswa dan sulitnya siswa memahami pelajaran biologi serta minimnya partisipasi dan prestasi siswa di kompetisi olimpiade sains. Hal ini disebabkan minimnya kratifitas dalam metode pembelajaran dan rendahnya semangat siswa dalam berkompetisi. Disisi lain, guru menghadapi kendala dalam menentukan metode pembelajaran biologi yang tepat dalam proses belajar mengajar, minimnya pengetahuan yang dimiliki guru dan siswa terutama di bidang biologi sel dan molekuler sehingga membutuhkan penguatan pengetahuan serta adanya minat yang kuat untuk menghasilkan prestasi di olimpiade sains nasional (OSN dan OGN) namun masih terkendala dengan sumber daya dan pengetahuan yang dimiliki serta masih ditemukan adanya kendala dalam menyelesaikan soal tipe higher order thingking skills (HOTS) yang sering muncul pada soal olimpiade sains.

Setelah melakukan analisis terhadap data yang ditemukan maka menghasilkan 
rekomendasi untuk melaksanakan kegiatan pengabdian berupa pendampingan melalui workshop sebagai jawaban atas permasalahan yang dihadapi serta sebagai upaya dalam meningkatkan kompetensi dan mutu pendidikan. Dalam kegiatan workshop ini, tim mengambil tema "Pembelajaran kompetisi inovasi IPTEK untuk guru dan siswa tingkat SMA" yang terdiri dari sosialisasi (ceramah dan diskusi) serta simulasi dan pelatihan. Sosialisasi (conceptual learning) meliputi 3 sesi dengan tujuan untuk menguatkan pemahaman dasar mengenai pembelajaran konsep biologi yaitu materi konsep dan penelitian biologi sel molekuler, aplikasi sains serta pembinaan dan penguatan materi olimpiade sains bidang biologi. Setelah sosialisasi, kegiatan dilanjutkan dengan simulasi dan pelatihan (procedural fluency) untuk menguatkan konsep yang telah diperoleh sehingga dapat memberikan pemahaman yang lebih baik kepada peserta. Kegiatan simulasi dan pelatihan mencakup contoh penerapan metode pembelajaran inovatif melalui pelatihan isolasi DNA organisme menggunakan bahan dan alat sederhana, praktek inovatif aplikasi sains dalam pembuatan teknologi sederhana serta simulasi kompetisi olimpiade sains nasional bidang biologi bagi guru dan siswa SMA menggunakan soal yang telah dikembangkan oleh tim pengabdian masyarakat bertipe HOTS. Soal olimpiade didesain oleh tim pengabdian masyarakat dan soal telah disetarakan dengan level kesulitan pada olimpiade sains nasional bidang biologi tingkat provinsi. Soal simulasi kompetisi olimpiade sains bidang biologi pada kegiatan ini terdiri dari 25 pertanyaan dengan 2 tipe soal (Gambar 2).

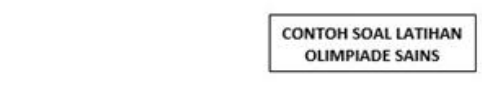

SOAL LATIHAN|

OLIMPIADE SAINS

PEMBEKALAN GURU MGMP BIOLOGI KABUPATEN SAMPANG MADURA

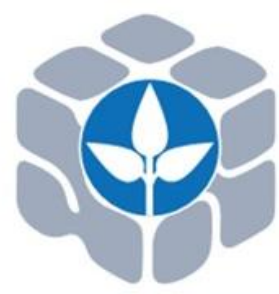

Bidang Biologi
(B)

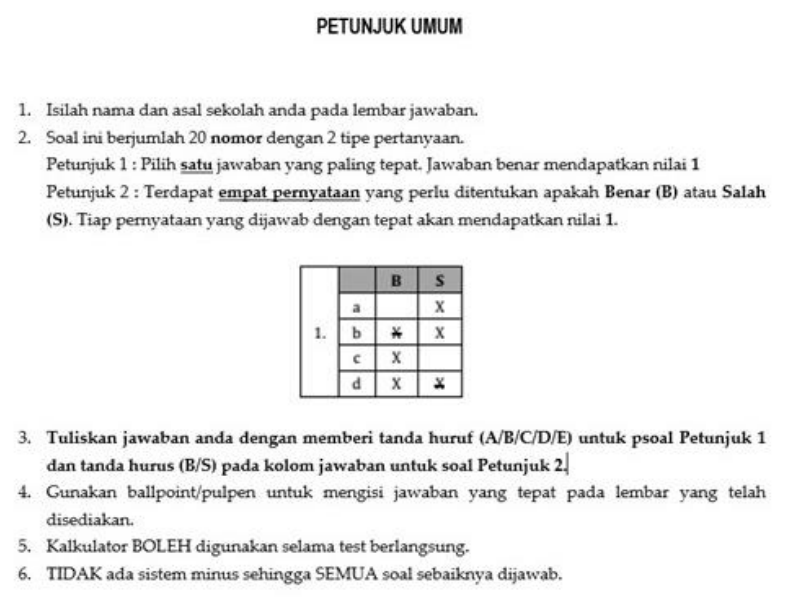

Waktu : 30 menit

Gambar 2. Tipe soal simulasi kompetisi olimpiade sains bidang biologi untuk guru dan siswa SMA di kabupaten Sampang. (A) halaman sampul berkas soal; (B) tipe soal yang diujikan

Kegiatan workshop yang dipadukan dengan conceptual learning dan procedural 
fluency menjadi sarana yang tepat sesuai kebutuhan mitra untuk menjawab permasalahan yang dihadapi sehingga mampu meningkatkan kompetensi guru dan siswa serta diharapkan berdampak pada peningkatkan mutu pendidikan dan pembelajaran. Mitra mendapatkan wawasan baru dari pakar, lalu melakukan diskusi interaktif dan sekaligus praktik metode pembelajaran dengan memanfaatkan bahan dan alat sederhana yang ada disekitar. Melalui kegiatan tersebut diharapkan antara lain sebagai berikut: (1) menjadi stimulus ide bagi guru untuk mengembangkan metode pembelajaran yang inovatif sesuai kebutuhan dan kondisi sekolah serta kondisi siswa sehingga siswa lebih mudah memahami pelajaran biologi; (2) meningkatnya pemahaman dan pengetahuan yang dimiliki guru dan siswa sehingga menjadi percaya diri dan mampu bersaing secara kompetitif pada kompetisi olimpiade; (3) meningkatnya penguasaan dan penyelesaian soal bertipe HOTS level olimpiade; (4) memicu minat dan semangat siswa untuk belajar; dan (5) metode pembelajaran yang inovatif dapat dirancang oleh core group dalam MGMP dan berupaya menerapkannya dalam kurikulum, maupun program kerja MGMP sehingga dihasilkan gerakan serentak dalam metode pembelajaran yang bermuara pada peningkatan mutu dan prestasi pendidikan.

\section{Pelaksanaan kegiatan dan evaluasi}

Pelaksanaan kegiatan pengabdian masyarakat melibatkan guru biologi dan siswa SMA di kabupaten Sampang sebagai peserta (Tabel 1.). Kegiatan diawali dengan melakukan persiapan melalui koordinasi internal maupun koordinasi dengan mitra sekaligus mempersiapkan bahan dan alat serta pembagian penugasan pada tim dan mitra sebagai bentuk penerapan metode CBR. Pelaksanaan kegiatan pengabdian ini dilakukan melalui pendekatan active based learning yaitu melibatkan peserta secara aktif dalam kegiatan pengabdian sehingga diharapkan peserta mendapatkan pembelajaran yang menghasilkan suatu manfaat bagi peserta. Kegiatan diawali dengan sambutan dari perwakilan dinas pendidikan kabupaten Sampang, lalu ketua MGMP biologi kabupaten Sampang dan ketua tim kegiatan pengabdian masyarakat. Perwakilan dari dinas pendidikan menyampaikan bahwa kegiatan ini sangat bermanfaat bagi guru dan siswa untuk meningkatkan mutu pendidikan apalagi selama ini terjadi kesenjangan antara sekolah negeri dan swasta sekaligus diharapkan output dari kegiatan ini nantinya bisa diimplementasikan dalam proses pembelajaran di sekolah. Ketua MGMP Biologi menyampaikan bahwa minat peserta yang ingin hadir mengikuti kegiatan ini sangat tinggi namun karena keterbatasan yang ada maka kegiatan ini hanya bisa diikuti oleh 60 peserta dari berbagai SMA negeri dan swasta di kabupaten Sampang.

Kegiatan sosialisasi dimulai dengan penguatan konsep biologi melalui ceramah (Gambar 3.). Ceramah diawali dengan penyampaian materi mengenai konsep dan penelitian biologi sel molekuler. Berdasarkan hasil diskusi sebelumnya dengan guru MGMP biologi, materi ini cukup sulit dipahami oleh guru dan siswa sehingga peserta membutuhkan penguatan materi ini. Ceramah dilakukan menggunakan metode pembelajaran yang inovatif melalui media power point dengan menampilkan gambar dan 
video biologi disertai dengan penjelasan menggunakan bahasa yang mudah dipahami sehingga guru dan siswa antusias mendengarkan. Metode pembelajaran ini menggabungkan kemampuan melihat dan mendengar sebagai contoh bagi guru agar nantinya cara ini bisa diterapkan ketika proses belajar mengajar di sekolah masingmasing. Pada saat sesi diskusi banyak sekali pertanyaan dari peserta yang menunjukkan minat yang tinggi peserta pada materi ini. Pada sosialisasi kedua membahas mengenai aplikasi ilmu sains menjadi teknologi sederhana dalam pembelajaran. Pada materi ini, peserta diberikan berbagai contoh metode pembelajaran yang inovatif dan menjadi bagian dari aplikasi sains dengan menerapkan teknologi sederhana yang bisa digunakan dalam pengembangan pembelajaran yang inovatif untuk meningkatkan minat belajar siswa sedangkan pada sosialisasi ketiga membahas tentang persiapan dan penguatan olimpiade sains bidang biologi bagi peserta yang mengkaji mengenai tips dan trik penyelesain soal olimpiade bertipe HOTS, motivasi untuk berprestasi dan berkompetisi serta diberikan berbagai rekomendasi kegiatan untuk meningkatkan skills dalam penyelesaian soal level olimpiade.

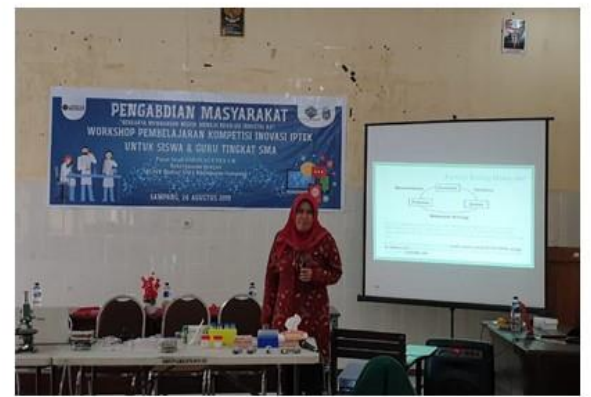

(A)

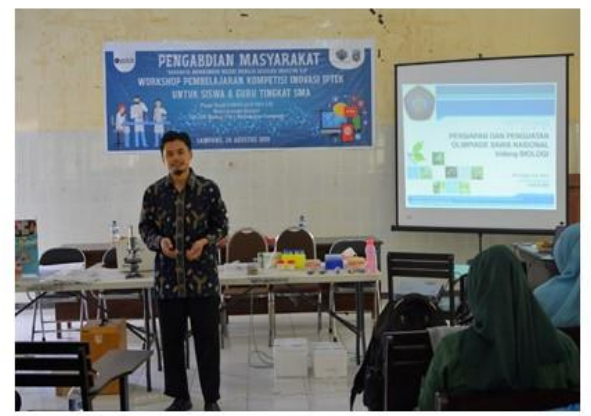

(C)

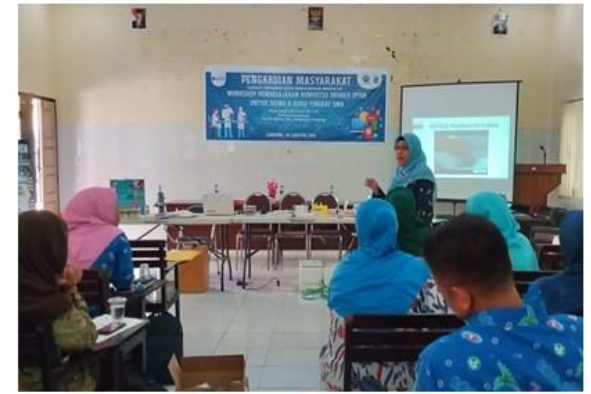

(B)

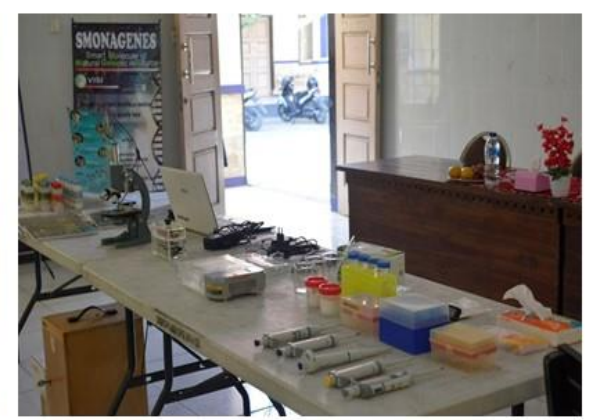

(D)

Gambar 3. Tim pengabdian masyarakat sedang menyampaikan materi. (A) penyampaian materi biologi sel dan molekuler beserta pengenalan bahan dan peralatan yang dapat digunakan selama pembelajaran biologi; (B) sosialisasi dan pelatihan aplikasi sains dalam pembelajaran; (C) sosialisasi kompetisi olimpiade sains; (D) beberapa bahan dan peralatan yang digunakan selama kegiatan.

Pada sosialisasi ketiga ini juga mengulas mengenai cakupan materi biologi pada 
OSN dan OGN, persiapan yang perlu dilakukan, dan penguatan kemampuan untuk meningkatkan pemahaman melalui berbagai ide yang ditawarkan oleh tim pengabdian masyarakat. Olimpiade sains adalah salah satu sarana bagi peserta didik dan guru untuk aktualisasi diri kemampuan yang dimiliki sebagai wujud dari pencapaian prestasi belajar mengajar di kelas sehingga kegiatan ini menjadi cerminan jaminan mutu proses pembelajaran dan pendidikan yang selama ini dilakukan. Setelah sosialisasi, kegiatan dilanjutkan dengan simulasi dan pelatihan yang diawali dengan penerapan metode pembelajaran inovatif melalui eksperimen atau praktikum teknik isolasi DNA organisme (Gambar 4.), praktek pembuatan teknologi sederhana kemudian dilanjutkan dengan simulasi pelatihan kompetisi olimpiade sains nasional bidang biologi bagi guru dan siswa SMA (Gambar 5.). Ketiga kegiatan ini bertujuan untuk menguatkan konsep yang telah diperoleh sehingga dapat memberikan pemahaman yang lebih baik kepada peserta.

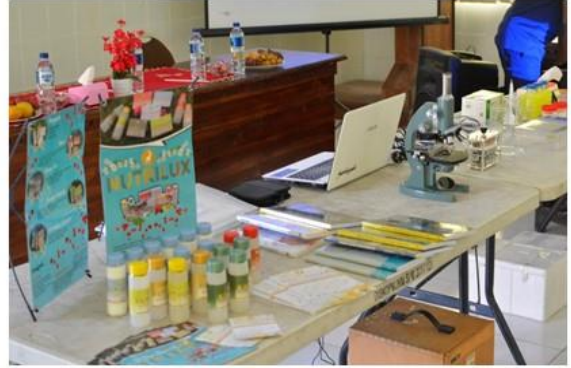

(A)

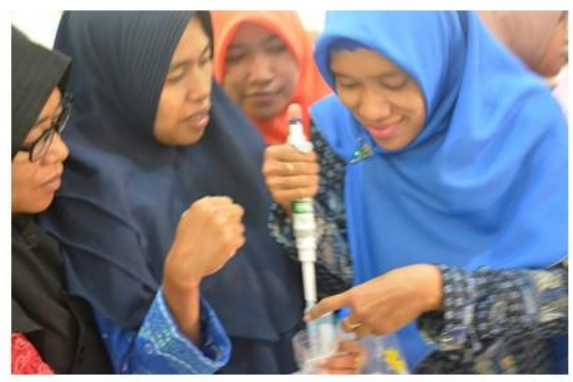

(C)

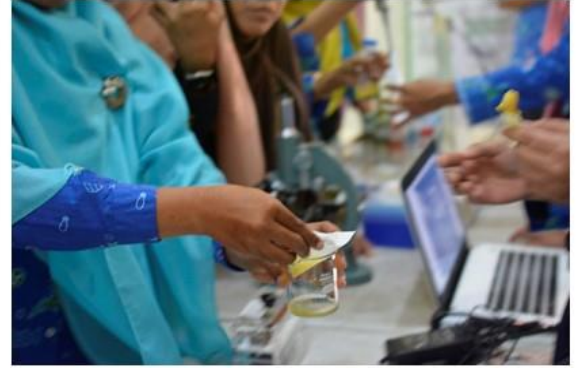

(B)

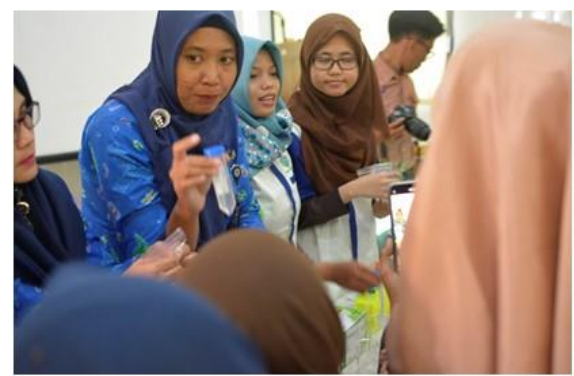

(D)

Gambar 4. Peserta sedang melaksanakan praktikum isolasi DNA organisme. (A) bahan dan alat yang digunakan selama praktikum; (B) proses penyaringan bahan; (C) pengambilan sampel; (D) penjelasan teknik isolasi DNA organisme.

Praktikum teknik isolasi DNA organisme menggunakan bahan yang mudah diperoleh sebagai upaya inovasi untuk mengatasi permasalahan mahalnya bahan baku standar yang digunakan saat isolasi DNA di laboratorium. Sebagian bahan tersebut antara lain buah nanas, daun, detergen bubuk, akuades, garam dapur dan alkohol. Pelatihan pembelajaran aplikasi sains dalam teknologi juga dilakukan melalui inovasi penggunaan bahan dan peralatan yang ada disekitar berdasarkan konsep sains. Melalui praktikum ini 
peserta dapat berinteraksi dengan objek biologi secara langsung sehingga memberikan pengalaman yang berharga dalam peningkatan kualitas pemahaman dan mutu pendidikan. Kemampuan yang dimiliki dari hasil praktikum akan mendorong peserta untuk berpikir kreatif dan aktif meneliti. Pada kegiatan setelahnya, peserta dihadapkan pada pembelajaran simulasi pelatihan kompetisi olimpiade sains untuk mengetahui kemampuan peserta dalam memahami ruang lingkup biologi melalui ujian dengan mengerjakan soal olimpiade selama kurang lebih 30 menit. Kegiatan ini membutuhkan aktifitas berpikir sehingga memerlukan energi yang besar.

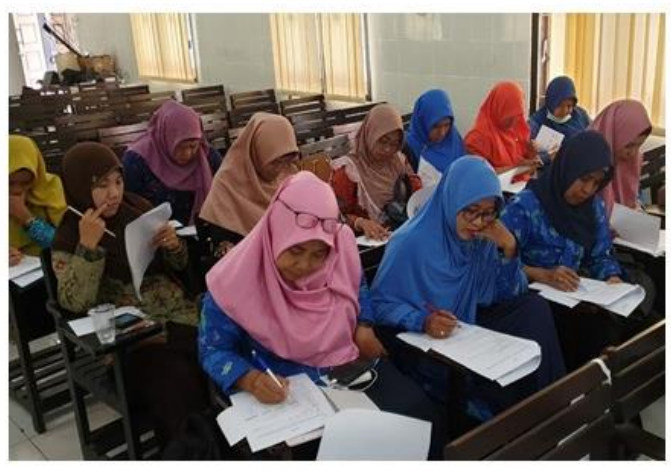

(A)

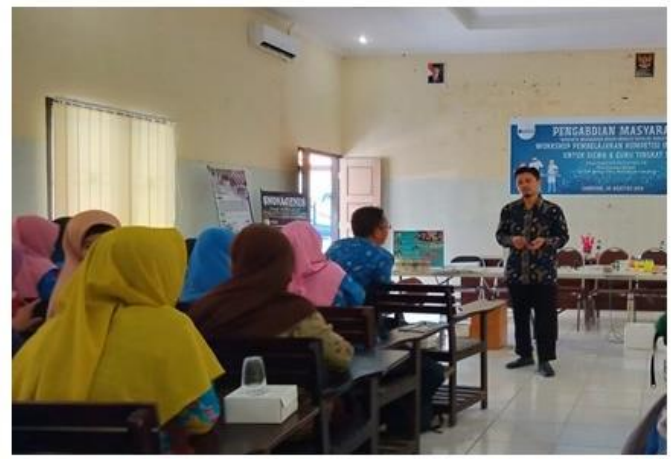

(B)

Gambar 5. Peserta mengerjakan soal simulasi kompetisi olimpiade sains bidang biologi yang sebelumnya telah mendapatkan pengarahan mengenai teknis pelaksanaan simulasi kompetisi.

Pengumpulan dan analisis data dilakukan dengan melibatkan mitra melalui penilaian penguasaan materi olimpiade biologi menggunakan skala nilai berdasarkan analisis nilai pada lembar jawaban soal olimpiade dari guru dan siswa serta pengisian kuesioner oleh guru dan siswa dengan 5 skala penilaian melalui teknik scoring. Berdasarkan hasil penilaian jawaban soal simulasi kompetisi olimpiade biologi menunjukkan bahwa rerata kemampuan dasar peserta dalam menjawab soal level olimpiade masih rendah (60-63\%) sedangkan yang memiliki kemampuan cukup hanya sekitar 6-10\% dari total peserta pada masing-masing kategori (guru dan siswa) (gambar 6). Hasil diskusi dan wawancara dengan peserta setelah kegiatan selesai dalam FGD diperoleh informasi bahwa mereka mengalami kesulitan dalam mengerjakan soal olimpiade biologi ini karena bertipe HOTS yang membutuhkan pendalaman materi dan kajian. Kondisi ini didukung juga oleh kenyataan bahwa peserta tidak terbiasa mengerjakan tipe soal seperti itu. Berdasarkan hasil penelitian ini, tim pengabdi menemukan fakta adanya kesulitan mitra dalam menyelesaikan tipe soal olimpiade dan masih minimnya pengetahuan tentang konsep materi yang sering diujikan pada soal olimpiade. Namun, hasil ini memberikan pengalaman belajar serta menguatkan kompetensi guru dan siswa. Oleh karena itu, hasil ini dapat dijadikan acuan untuk kegiatan pengabdian masyarakat di masa mendatang sehingga kegiatan nantinya dapat lebih fokus pada pendampingan dan pembinaan peserta dalam rangka menghadapi 
olimpiade. Sebagai awal dari itu, perwakilan guru biologi dari tiap sekolah mulai menyadari pentingnya meningkatkan kompetensi diri dan inovasi metode pembelajaran agar mampu meningkatkan pemahaman. Meningkatnya pemahaman siswa akan memudahkan siswa dalam berkompetisi di olimpiade. Bentuk aplikatif dari kesadaran ini yaitu komitmen setiap guru biologi untuk menerapkan ilmu yang diperoleh selama workshop di sekolah masing-masing melalui penerapan inovasi pembelajaran dan peningkatan pelatihan mengerjakan soal olimpiade. Tim pengabdi juga menyampaikan dukungan kesediaan mendampingi lebih lanjut melalui forum media online.

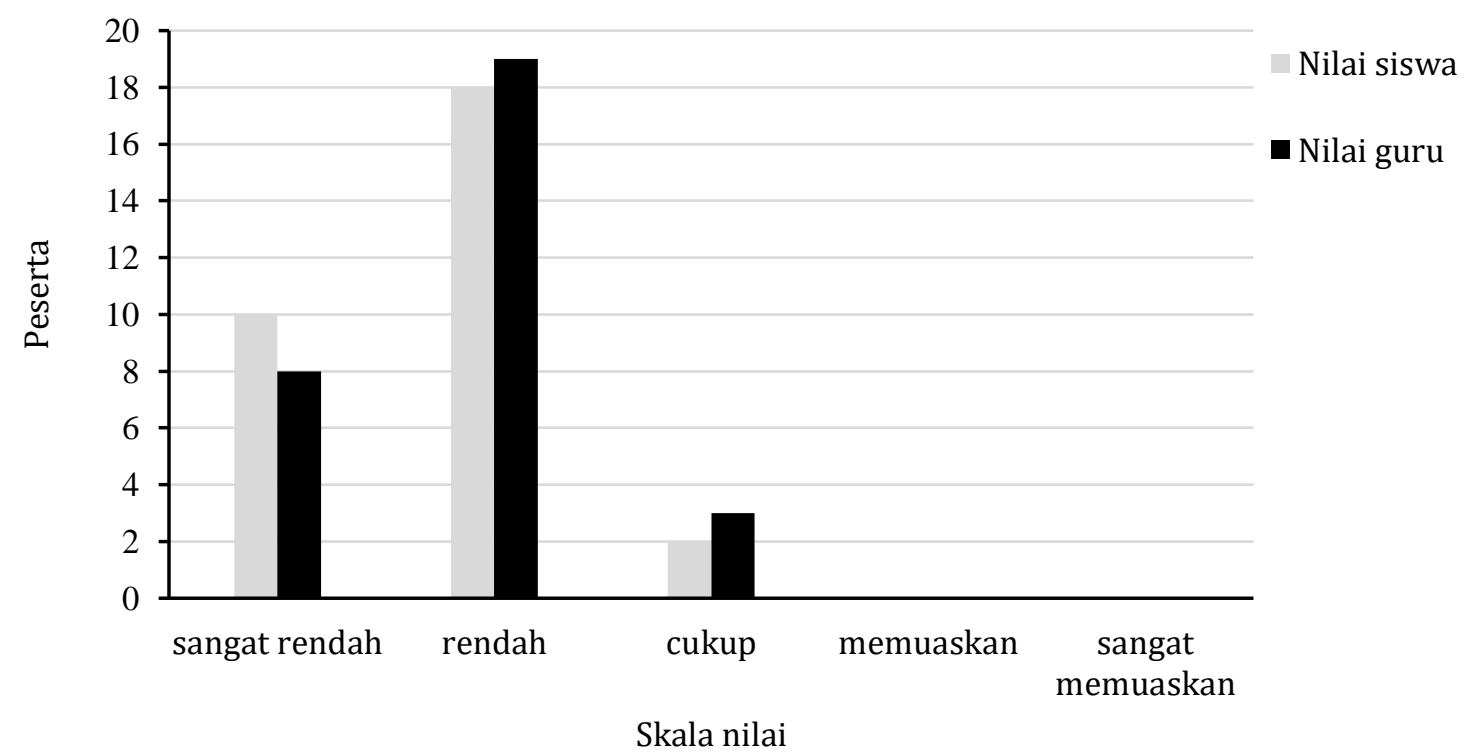

Gambar 6. Profil skala nilai peserta setelah mengerjakan soal simulasi kompetisi olimpiade sains bidang biologi.

Pada saat FGD juga dilakukan diskusi untuk mencari solusi sebagai upaya meningkatkan kompetensi, kemampuan dan pengetahuan mitra dalam pengembangan metode pembelajaran yang inovatif dan peningkatan pengetahuan dalam kompetisi olimpiade biologi dengan tujuan akhir adalah peningkatan mutu pendidikan. Tim pengabdi memberikan ide dan gagasan yang bisa diterapkan dalam metode pembelajaran biologi di sekolah dan program kerja MGMP terkait dengan peningkatan skills penyelesaian soal olimpiade antara lain sebagai berikut: (1) menerapkan pemikiran kreatif dan inovatif dalam metode pembelajaran biologi melalui praktikum dengan menggunakan bahan yang bisa ditemukan di sekitar, menggunakan media power point dengan menampilkan gambar dan video biologi yang bisa diunduh dari aplikasi (kombinasi visual, mendengar dan motorik) dan melibatkan secara aktif siswa dalam proses pembelajaran; (2) mengadakan kegiatan rutin diskusi atau latihan mengerjakan soal level olimpiade dalam bentuk kelompok kerja (grup); (3) melakukan kerjasama dengan instansi terkait untuk mengadakan pra kompetisi olimpiade internal atau antar sekolah se-kabupaten; (4) kerjasama dengan perguruan tinggi dalam rangka pendampingan secara intensif; (5) merencanakan program kerja yang berorientasi pada peningkatan mutu pendidikan; dan (6) perlu diadakan kegiatan lanjutan dalam 
pembinaan olimpiade dan kelas olimpiade di tiap sekolah. Dari kegiatan ini memunculkan kesadaran bersama untuk berupaya menerapkan rekomendasi dalam pembahasan program kerja di MGMP dan berupaya melakukan perubahan terhadap proses dan metode pembelajaran biologi di sekolah. Langkah positif diambil oleh tim pengabdian masyarakat dengan memberikan hadiah kepada peserta yang mendapatkan nilai tertinggi guna memotivasi peserta untuk terus belajar dan berprestasi (Gambar 7).

Tabel 2. Profil Hasil Kuesioner

\begin{tabular}{|c|c|c|c|c|c|c|}
\hline \multirow[b]{2}{*}{ No } & \multirow{2}{*}{ Pertanyaan } & \multicolumn{5}{|c|}{ Skala nilai (\%) } \\
\hline & & 1 & 2 & 3 & 4 & 5 \\
\hline 1 & $\begin{array}{l}\text { Secara garis besar bagaimana penilaian Anda terhadap } \\
\text { workshop ini? }\end{array}$ & & & & 73 & 27 \\
\hline 2 & Penilaian terhadap topik workshop & & & & 87 & 13 \\
\hline 3 & $\begin{array}{l}\text { Penilaian terhadap manfaat atas informasi yang } \\
\text { dipresentasikan/diberikan }\end{array}$ & & & & 67 & 33 \\
\hline 4 & Penilaian terhadap kualitas presentasi & & & & 87 & 13 \\
\hline 5 & Penilaian terhadap alat peraga dalam praktek & & & & 40 & 60 \\
\hline 6 & $\begin{array}{l}\text { Penilaian terhadap materi yang diberikan selama } \\
\text { worshop berlangsung }\end{array}$ & & & & 93 & 7 \\
\hline 7 & $\begin{array}{l}\text { Bagaimana tingkat pemahaman Anda terhadap } \\
\text { presentasi yang diberikan }\end{array}$ & & & 100 & & \\
\hline 8 & $\begin{array}{l}\text { Penguasaan materi/kemampuan instruktur } \\
\text { Laboratorium }\end{array}$ & & & & 67 & 33 \\
\hline 9 & $\begin{array}{l}\text { Pelayanan instruktur terhadap keberlangsungan } \\
\text { proses pelatihan }\end{array}$ & & & & 60 & 40 \\
\hline 10 & $\begin{array}{l}\text { Keterserdiaan media pelatihan selama workshop } \\
\text { berlangsung (alat bahan dll) }\end{array}$ & & & & 40 & 60 \\
\hline 11 & $\begin{array}{l}\text { Penilaian tentang pengaturan workshop : undangan } \\
\text { dan daftar hadir }\end{array}$ & & & & 73 & 27 \\
\hline 12 & $\begin{array}{l}\text { Penilaian tentang pengaturan workshop : penjadwalan } \\
\text { dan waktu kegiatan }\end{array}$ & & & & 87 & 13 \\
\hline 13 & $\begin{array}{l}\text { Penilaian tentang pengaturan workshop: pemilihan } \\
\text { fasilitas/tempat kegiatan }\end{array}$ & & & & 73 & 27 \\
\hline 14 & $\begin{array}{l}\text { Penilaian tentang pengaturan workshop: makanan dan } \\
\text { minuman }\end{array}$ & & & & 73 & 27 \\
\hline 15 & $\begin{array}{l}\text { Berdasarkan partisipasi Anda dalam workshop kali ini, } \\
\text { seberapa besar kemungkinan Anda untuk } \\
\text { berpartisipasi dalam workshop selanjutnya }\end{array}$ & & & $\mathrm{ku}$ & sar & \\
\hline 16 & $\begin{array}{l}\text { Apa bagian paling favorit untuk Anda dalam workshop } \\
\text { ini? }\end{array}$ & & 1 & orak & kum & \\
\hline 17 & $\begin{array}{l}\text { Apa bagian paling menarik untuk Anda dalam } \\
\text { workshop ini? }\end{array}$ & & i D & & & \\
\hline
\end{tabular}

Secara umum, kegiatan pengabdian masyarakat ini dinyatakan berhasil 
berdasarkan evaluasi kehadiran peserta yang mengikuti kegiatan dari awal hingga akhir yaitu $100 \%$ peserta hadir. Selain itu, peserta juga antusias selama kegiatan dengan aktif terlibat, bertanya dan berdiskusi serta menunjukkan minat dan keinginan yang kuat untuk belajar dan meningkatkan kompetensi yang dimiliki. Hasil evaluasi menggunakan kuesioner juga menunjukkan bahwa kegiatan ini dirasakan manfaatnya oleh peserta. Kegiatan simulasi dan pelatihan menjadi kegiatan yang paling diminati oleh peserta terutama pada saat pelatihan teknik isolasi DNA (Tabel 2). Peserta juga merasakan bertambahnya pengetahuan dan wawasan mengenai soal olimpiade biologi serta mendapatkan ketrampilan dalam menjawab soal biologi level olimpiade. Selama kegiatan peserta sangat antusias untuk bertanya dan berdiskusi tentang materi yang diberikan sehingga memunculkan ide dan gagasan lain dalam inovasi pembelajaran yang bisa dikembangkan dan diterapkan di sekolah untuk meningkatkan kualitas pembelajaran biologi. Setelah tim memperolah data dari kegiatan ini maka diharapkan ke depan kegiatan pengabdian masyarakat akan diarahkan kepada peningkatan nilai dan kemampuan peserta dalam menyelesaikan soal olimpiade melalui pelatihan dan pendampingan secara intensif.

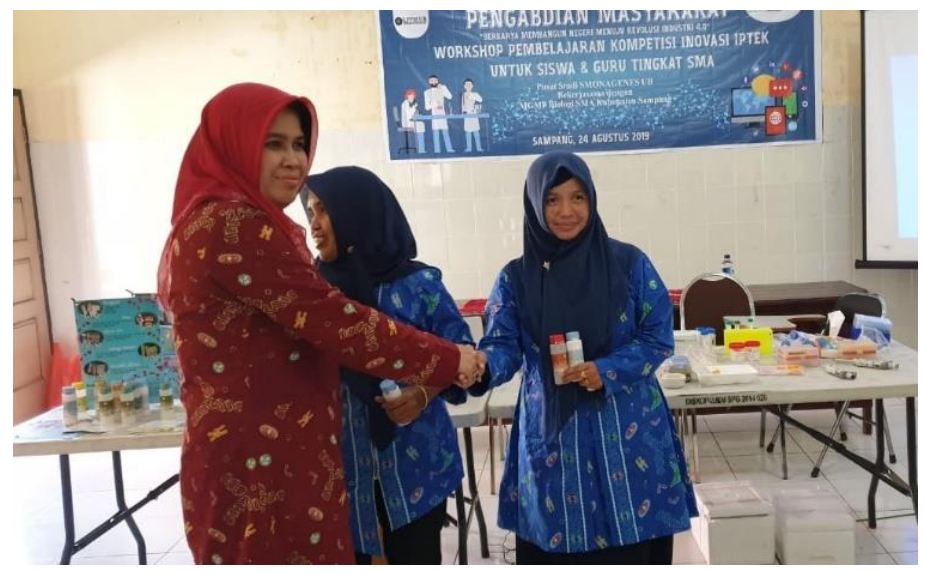

Gambar 7. Pemberian hadiah produk NUTRILUX kepada pesera yang memperoleh nilai tertinggi pada pembelajaran simulai kompetisi olimpiade biologi.

\section{Diskusi}

Berdasarkan hasil yang diperoleh selama melaksanakan kegiatan menunjukkan bahwa terjadi perubahan berpikir yang diikuti dengan komitmen untuk menerapkan ilmu yang diperoleh di sekolah masing-masing dimana guru semakin menyadari tentang pentingnya meningkatkan kompetensi terutama dalam hal mengembangkan wawasan keilmuan dan inovasi metode pembelajaran agar memudahkan siswa memahami pelajaran sehingga dapat membantu siswa untuk meningkatkan kompetensi dan mencapai tujuan belajar. Peningkatan kompetensi yang dimiliki oleh guru menjadi penting karena belajar adalah proses pengembangan pengetahuan, keterampilan dan tingkah laku yang membutuhkan peran guru sebagai pendidik untuk menyampaikan 
materi dengan baik ke siswa ${ }^{23}$.

Selain itu, guru juga perlu terus meningkatkan kompetensi standar yang mencakup penguasaan materi, pemahaman terhadap siswa, metode pembelajaran, pengembangan pribadi dan profesionalitas ${ }^{24}$. Oleh karena itu, bila minat belajar dan daya tangkap siswa masih kurang terhadap materi yang diberikan oleh guru maka hal ini bisa bermula dari minimnya pengetahuan dan tiadanya inovasi dalam metode pembelajaran sehingga siswa sulit memahami pelajaran yang diberikan karena metode pembelajaran terkesan kaku dan monoton ${ }^{25}$. Penguatan kompetensi individu dapat dilakukan melalui penerapan metode pembelajaran yang tepat. Menurut model kerucut pengalaman belajar menunjukkan bahwa metode belajar melalui kombinasi melihat dan mendengar akan menghasilkan pemahaman yang lebih baik dibandingkan bila hanya melihat atau mendengar saja karena hal ini melibatkan peran dua panca indera sehingga informasi lebih mudah diserap sekaligus memperkuat daya ingat ${ }^{26}$.

Dalam kegiatan pendampingan ini, selain menyampaikan konsep biologi untuk menguatkan kompetensi pengetahuan, tim pengabdi juga berupaya menguatkan kompetensi guru dan siswa melalui pengembangan inovasi sains dan simulasi kompetisi olimpiade menggunakan kombinasi pembelajaran yang inovatif melalui media power point dengan menampilkan gambar dan video biologi, pelatihan dan praktikum menggunakan bahan yang mudah diperoleh serta simulasi kompetisi. Kombinasi ini sangat tepat karena dapat memperjelas penyampaian materi pembelajaran ${ }^{27}$. Metode pembelajaran ini menggabungkan kemampuan melihat, mendengar dan motorik sebagai contoh bagi guru agar nantinya metode ini bisa diterapkan ketika proses belajar mengajar di sekolah masing-masing yang disertai dengan pengembangan inovasi secara berkelanjutan. Metode tersebut menekankan keterlibatan aktif peserta dimana peserta sebagai pusat pembelajaran sehingga peserta menjadi lebih antusias, interaktif dan minat belajar meningkat serta peserta merasa lebih mudah memahami materi yang disampaikan. Metode pembelajaran seperti ini dapat meningkatkan pemahaman dan kompetensi peserta karena memberikan kesempatan mempelajari keterampilan berbasis pengetahuan yang dimiliki serta mengembangkan kemampuan berpikir dan kreativitas secara optimal ${ }^{28}$. Hal ini menjadi penting karena mempelajari ilmu biologi

\footnotetext{
${ }^{23}$ Suci Lestari, “Analisis Kemampuan Technological Pedagogical Content Knowledge (TPACK) Pada Guru Biologi SMA Dalam Materi Sistem Saraf," in Seminar Nasional XII FKIP UNS, vol. 46, 2015, 557-564.

24 Jejen Musfah, Peningkatan Kompetensi Guru Melalui Pelatihan Dan Sumber Belajar : Teori Dan Praktik (Jakarta: Penerbit Kencana, 2011).

${ }^{25}$ Rohman, "Penerapan Model Pembelajaran Kooperatif Tipe CIRC Untuk Meningkatkan Hasil Belajar Konsep Metabolisme Dan Respon Peserta Didik Kelas XII IPA-7 SMA Negeri 1 Sampang Tahun Pelajaran 2011/2012"; Listiana, "Realitas Pengembangan Keterampilan Berpikir Dalam Pembelajaran Biologi: Studi Pendahuluan Di SMA Muhammadiyah Se-Surabaya."

${ }^{26}$ Arsyad, Media Pembelajaran. (Jakarta: Rajawali Press, 2011).

27 Sudjana and Rivai, Media Pengajaran; Munadi, Media Pembelajaran (Jakarta: GP Press, 2013).

28 R. Iswari, "Upaya Meningkatkan Kemampuan Guru Sma Mengajar Biologi Dengan Metode Pembelajaran Aktif, Kreatif, Inovatif, Dan Menyenangkan Di Mgmp Biologi Kabupaten Demak," Jurnal Abdimas 14, no. 1 (2010): 25504; Mahwar Qurbaniah and Nurdianti Awaliyah, "Eksperimen Sains Berbasis
} 
membutuhkan beberapa kemampuan yang baik yaitu kemampuan memahami, memecahkan masalah, dan pengalaman terlibat secara langsung 29 .

Bentuk utama kegiatan yang digunakan dalam pengabdian ini berupa workshop dengan perpaduan conceptual learning, procedural fluency dan active based learning yang dirasakan efektif oleh mitra sehingga mitra merasakan manfaat dari kegiatan ini. Bentuk kegiatan ini merupakan salah satu sarana yang efektif dalam upaya meningkatkan pengetahuan, kemampuan dan kualitas pembelajaran karena memungkinkan terjadi diskusi interaksi dua arah, pertukaran informasi dan gagasan maupun penguatan wawasan ilmu pengetahuan guru dan siswa. Selain itu juga meningkatkan minat dan skills guru dan siswa serta menumbuhkan jiwa kompetisi untuk meningkatkan pengetahuan.

Simulasi kompetisi olimpiade yang diadakan juga merangsang daya juang untuk berprestasi walaupun hasil pada saat simulasi belum sesuai dengan yang diharapkan. Namun, semangat yang ditunjukkan oleh mitra memberikan energi positif bagi pengembangan pembelajaran di masa depan serta memberikan penguatan kompetensi dan kesaadaran untuk terus berkembang. Rendahnya nilai hasil simulasi olimpiade disebabkan oleh beberapa hal seperti minimnya pengalaman peserta dalam mengerjakan soal tipe olimpiade (HOTS), ketidaktelitian dalam mengerjakan soal, dan kurangnya pemahaman keilmuan ${ }^{30}$. Tipe soal ini membutuhkan daya pemahaman yang kuat dan kemampuan berpikir analisis. Walaupun pembelajaran kompetisi olimpiade sains bidang biologi untuk guru dan siswa menghasilkan rerata nilai yang rendah namun guru dan siswa merasakan bertambahnya pengetahuan dan wawasan mereka. Bagaimanapun, pengalaman yang diperoleh dari simulasi kompetisi olimpiade ini memberikan hal positif bagi peserta dalam upaya meningkatkan kompetensi sebagaimana menurut Hamidah ${ }^{31}$ dan Hatchi ${ }^{32}$ bahwa kebiasaan mengerjakan soal tipe HOTS akan meningkatkan kompetensi individu dan meningkatkan mutu penilaian. Dengan begitu maka kemampuan peserta dapat ditingkatkan di masa mendatang. Kegiatan pembelajaran simulasi kompetisi olimpiade biologi ini bertujuan untuk mengetahui tingkat pemahaman dan kemampuan dasar peserta dalam mengerjakan soal level olimpiade biologi sehingga hasil kegiatan ini menunjukkan ketercapaian sasaran kegiatan. Untuk meningkatkan kompetensi maka beberapa saran dari tim pengabdian masyarakat kepada peserta yaitu: (1) seharusnya memiliki pemahaman yang baik dan kokoh; (2)

Kreasi Warna Alami Sebagai Inovasi Dalam Pembelajaran Biologi,” Al-khidmah 1, no. 2 (2018): 93.

${ }^{29}$ Elvan Ince Aka, Ezgi Güven, and Mustafa Aydoğdu, "Effect of Problem Solving Method on Science Process Skills and Academic Achievement," Journal of Turkish Science Education 7, no. 4 (2010): 13-25; Listiana, "Realitas Pengembangan Keterampilan Berpikir Dalam Pembelajaran Biologi: Studi Pendahuluan Di SMA Muhammadiyah Se-Surabaya."

${ }^{30}$ Siti Sara, Suhendar Suhendar, and Rizqi Yanuar Pauzi, "Profil Higher Order Thinking Skills (HOTS) Siswa Sekolah Menengah Pertama (SMP) Kelas VIII Pada Materi Sistem Pernapasan," Bioedusiana: Jurnal Pendidikan Biologi 5, no. 1 (2020): 42.

31 Luluk Hamidah, Higher Order Thinking Skills (Yogyakarta: Hijaz Pustaka Mandiri, 2018).

32 Itgo Hatchi et al., "Pendekatan Metakognitif Dalam Proses Kemampuan High Order Thinking Skills Siswa," Prosiding Seminar Nasional Multidisiplin Ilmu Universitas Asahan 3 (2019): 415-428. 
melakukan dengan cara yang benar, sistematis dan terkonsep; (3) memberi teladan; (4) kemampuan analisa yang cermat; dan (5) meningkatkan kecerdasan spiritual. Tim pengabdian juga memberikan saran untuk sering mengadakan kompetisi serupa di level sekolah masing-masing sehingga menciptakan tradisi untuk berprestasi, mengadakan diskusi dan latihan mengerjakan soal serta melakukan pembinaan dan pendampingan olimpiade secara intensif.

Melalui kegiatan simulasi dan pelatihan yang mencakup pembelajaran praktikum dan kompetisi olimpiade memberikan pengalaman belajar yang baik bagi peserta. Strategi pembelajaran ini meningkatkan efektivitas dalam memahami karena melibatkan pengalaman personal melalui observasi langsung (menyimak, melihat, membaca dan mendengar), asosiasi, diskusi, menyimpulkan dan komunikasi ${ }^{33}$. Hal ini akan memudahkan peserta dalam mempelajari biologi karena dapat mengamati objek biologi secara langsung dan didukung dengan media pembelajaran yang inovatif. Melalui kegiatan ini peserta dapat melakukan praktek dan pengamatan sehingga mudah mengingat kembali serta peserta mendapatkan pengalaman belajar secara langsung melalui proses pembelajaran ini. Pengalaman yang diperoleh ini akan membantu peserta untuk mendapatkan pengetahuan secara lebih luas sehingga sangat mendukung perkembangan cara berpikir peserta.

\section{Kesimpulan}

Pembelajaran biologi menggunakan kombinasi metode pembelajaran yang inovatif sangat diperlukan untuk meningkatkan daya pemahaman dan kompetensi. Kegiatan pendampingan melalui workshop, simulasi dan pelatihan menjadi kegiatan yang paling diminati oleh mitra sehingga mampu menguatkan pemahaman dan kompetensi mitra, memicu daya inovasi, meningkatkan semangat dan minat mitra dalam pembelajaran biologi serta memberikan bekal pengalaman yang berharga bagi mitra. Selain itu, kegiatan pengabdian melalui pembelajaran inovasi sains dan kompetisi olimpiade biologi juga mencerminkan profil kompetensi guru dan siswa saat ini serta menumbuhkan kesadaran untuk meningkatkan kompetensi melalui komitmen menerapkan ilmu yang diperoleh di sekolah masing-masing dalam berbagai bentuk kegiatan aplikatif sehingga memungkinkan untuk ditingkatkan di masa mendatang sebagai upaya peningkatan prestasi dan mutu pendidikan di kabupaten Sampang.

\section{Pengakuan}

Penulis mengucapkan terimakasih kepada Lembaga Penelitian dan Pengabdian

${ }^{33}$ Destri Ratna Ma'rifah and I Gusti Putu Suryadarma, "Penyusunan Panduan Edutourism Hutan Wisata Tlogo Nirmolo Guna Memunculkan Karakter Peserta Didik Kelas X," Jurnal Inovasi Pendidikan IPA 1, no. 2 (2015): 126-137. 
kepada Masyarakat Universitas Brawijaya (LPPM UB) yang telah memberikan dukungan finansial dalam kegiatan pengabdian masyarakat ini.

\section{Daftar Referensi}

Aka, Elvan Ince, Ezgi Güven, and Mustafa Aydoğdu. "Effect of Problem Solving Method on Science Process Skills and Academic Achievement." Journal of Turkish Science Education 7, no. 4 (2010): 13-25.

Arifin, Syamsul. "Kemitraan Sekolah-Masyarakat Sebagai Upaya Peningkatan Mutu Pendidikan Di Sampang, Jawa Timur." Jurnal Humanity 8, no. 1 (2012): 203-219.

Arsyad, A. Media Pembelajaran. Jakarta: Rajawali Press, 2011.

Arthayanti, Yani, I Gusti Ayu Made Srinadi, and G.K. Gandhiadi. “Geographically Weighted Ridge Regression Dalam Kasus Multikolinearitas Pada Indeks Pembangunan Manusia Di Kabupaten/Kota Provinsi Jawa Timur." Jurnal Matematika 7, no. 2 (2017): 124-131.

Badan Pusat Statistik. Jawa Timur Dalam Angka 2020. Surabaya: BPS Surabaya, Jawa Timur, 2020.

Doyan, Aris, Susilawati Susilawati, Harry Soeprianto, and Syamsul Bahri. "Pelatihan Olimpiade MIPA Bagi Guru Dan Peserta Didik SMA Kesuma Mataram." Jurnal Pengabdian Magister Pendidikan IPA 1, no. 1 (2018): 20-23.

Erfan, Muhammad, Tursina Ratu, Fahmi Yahya, Sri Nurul Walidain, and Syarif Fitriyanto. "Pendampingan Persiapan Olimpiade Sains Nasional (OSN) Tingkat Kabupaten Bagi Siswa SMA Negeri 4 Sumbawa." Jurnal Pendidikan dan Pengabdian Masyarakat 2, no. 1 (2019): 114-119.

Hacker, Karen, Shalini A Tendulkar, Catlin Rideout, Nazmim Bhuiya, Chau Trinh-Shevrin, Clara P Savage, Milagro Grullon, Hal Strelnick, Carolyn Leung, and Ann DiGirolamo. "Community Capacity Building and Sustainability: Outcomes of Community-Based Participatory Research.” Prog. Community Health Partnership 6, no. 3 (2012): 349360.

Hafiyusholeh, Moh, Ahmad Lubab, Ahmad Hanif Asyhar, Aris Fanani, Yuniar Farida, Dian C. Rini Novitasari, Nurissaidah Ulinnuha, et al. "Pendampingan Guru Madrasah Untuk Mewujudkan Kompetensi Pedagogik Guru Matematika Yang Berdaya Melalui Penguasaan Soal High Order Thinking Skills (HOTS)." Engagement: Jurnal Pengabdian Kepada Masyarakat 4, no. 1 (2020): 183-200.

Hamidah, Luluk. Higher Order Thinking Skills. Yogyakarta: Hijaz Pustaka Mandiri, 2018. 
Hatchi, Itgo, Dwi Aninditya Siregar, Lia Purnama, and Sari Suryadi. "Pendekatan Metakognitif Dalam Proses Kemampuan High Order Thinking Skills Siswa." Prosiding Seminar Nasional Multidisiplin Ilmu Universitas Asahan 3 (2019): 415428.

Iswari, R. “Upaya Meningkatkan Kemampuan Guru Sma Mengajar Biologi Dengan Metode Pembelajaran Aktif, Kreatif, Inovatif, Dan Menyenangkan Di Mgmp Biologi Kabupaten Demak." Jurnal Abdimas 14, no. 1 (2010): 25504.

Kementerian Pendidikan dan Kebudayaan. Pedoman Olimpiade Sains Nasional Tahun 2019. Jakarta: Direktorat Jenderal Pendidikan Dasar dan Menengah, 2019.

Kementerian Pendidikan dan Kebudayaan. Pedoman Pelaksanaan Olimpiade Guru Nasional (OGN) Pendidikan Menengah Dan Pendidikan Khusus. Jakarta: Direktorat Pembinaan Guru Pendidikan Menengah dan Pendidikan Khusus, 2019.

Lestari, Suci. "Analisis Kemampuan Technological Pedagogical Content Knowledge (TPACK) Pada Guru Biologi SMA Dalam Materi Sistem Saraf." In Seminar Nasional XII FKIP UNS, 46:557-564, 2015.

Listiana. "Realitas Pengembangan Keterampilan Berpikir Dalam Pembelajaran Biologi: Studi Pendahuluan Di SMA Muhammadiyah Se-Surabaya." In Prosiding Seminar Nasional Dan Workshop Nasional Biologi/IPA Dan Pembelajarannya, 340-347. Malang: FMIPA Jurusan Biologi Universitas Negeri Malang, 2014.

Lumbantorum, Eka Pratiwi, and Paidi Hidayat. "Analisis Pertumbuhan Ekonomi Dan Indeks Pembangunan Manusia (IPM) Provinsi-Provinsi Di Indonesia (Metode Kointegrasi)." Jurnal Ekonomi dan Keuangan 2, no. 2 (2014): 14-27.

Ma'rifah, Destri Ratna, and I Gusti Putu Suryadarma. "Penyusunan Panduan Edutourism Hutan Wisata Tlogo Nirmolo Guna Memunculkan Karakter Peserta Didik Kelas X." Jurnal Inovasi Pendidikan IPA 1, no. 2 (2015): 126-137.

Majid, Abdul. Perencanaan Pembelajaran: Mengembangkan Standar Kompetensi Guru. Bandung: PT Remaja Rosdakarya, 2013.

Muhid, Abdul, Sumarkan, Rakhmawati, and Lukman Fahmi. "Perubahan Perilaku Open Defecation Free ( ODF ) Melalui Program Sanitasi Total Berbasis Masyarakat ( STBM ) Di Desa Babad." Engagement; Jurnal Pengabdian Kepada Masyarakat 2, no. 1 (2018): 99-119.

Muliani, Fitra, Dewi Noviati, and Fajriani. "Pembinaan Peningkatan Mutu Pendidikan Bidang Olimpiade Sains Bagi Guru Sd Kota Langsa Provinsi Aceh." Jurnal Pengabdian Masyarakat Universitas Merdeka Malang 3, no. 2 (2018): 9-13.

Mulligan, Martin, and Yaso Nadarajah. "Working on the Sustainability of Local Communities with a 'Community-Engaged' Research Methodology." Local Environment 13, no. 2 (2008): 81-94. 
Munadi. Media Pembelajaran. Jakarta: GP Press, 2013.

Musfah, Jejen. Peningkatan Kompetensi Guru Melalui Pelatihan Dan Sumber Belajar : Teori Dan Praktik. Jakarta: Penerbit Kencana, 2011.

Putra, Rangga Sa'adillah Sandhy Atma. “Pembelajaran Pendidikan Agama Islam Melalui Pendekatan Saintifik Dalam Membentuk Sikap Spiritual Siswa Sekolah Menengah Atas Di Sidoarjo (Studi Fenomenologi Pengalaman Guru Dan Siswa Pada SMA Di Sidoarjo)." Universitas Muhammadiyah Malang, 2020. http://eprints.umm.ac.id/65683/.

Qurbaniah, Mahwar, and Nurdianti Awaliyah. "Eksperimen Sains Berbasis Kreasi Warna Alami Sebagai Inovasi Dalam Pembelajaran Biologi.” Al-khidmah 1, no. 2 (2018): 93.

Rohman, Syaiful. "Penerapan Model Pembelajaran Kooperatif Tipe CIRC Untuk Meningkatkan Hasil Belajar Konsep Metabolisme Dan Respon Peserta Didik Kelas XII IPA-7 SMA Negeri 1 Sampang Tahun Pelajaran 2011/2012." Jurnal Pena Sains 2, no. 1 (2015): 7-13.

S.A.P., Rangga Sa'adillah, Tobroni, Ishomuddin, and Khozin. "Dampak Pendekatan Saintifik Terhadap Sikap Spiritual Siswa Dalam Pembelajaran PAI Di SMA Di Sidoarjo." Jurnal Pendidikan Agama Islam (Journal of Islamic Education Studies) 7, no. 2 (2019): 143-165.

Sara, Siti, Suhendar Suhendar, and Rizqi Yanuar Pauzi. "Profil Higher Order Thinking Skills (HOTS) Siswa Sekolah Menengah Pertama (SMP) Kelas VIII Pada Materi Sistem Pernapasan." Bioedusiana: Jurnal Pendidikan Biologi 5, no. 1 (2020): 42.

Sarah Banks, and Paul Manners. Community-Based Participatory Research: A Guide to Ethical Principles and Practice. Durham, UK: Center for Social Justice and Community Action, Durham University, 2012.

Sari, Indah Purnama, Bado Riyono, and Agus Supandi. "Indeks Pembangunan Manusia Di Madura: Analisis Tipologi Klassen." Journal of Applied Business and Economics 6, no. 2 (2019): 82-95.

Slameto. Belajar Dan Faktor-Faktor Yang Mempengaruhi. Jakarta: Rineka Cipta, 2010.

Sudjana, and Rivai. Media Pengajaran. Bandung: Sinar Baru Algensido, 2010.

Surabaya, Tim Penyusun Panduan CBR UIN Sunan. Community Based Research : Sebuah Pengantar. Surabaya: SILE/LLD, 2015.

Wajdi, Muh Barid Nizarudin, M Burhanuddin Ubaidillah, Sri Mulyani, Khoirul Anwar, Lailatul Istiqomah, Fauziyah Rahmawati, Sholihatul Atik Hikmawati, Diah Retno Ningsih, and Hasan Syaiful Rizal. "Pendampingan Redesign Pembelajaran Masa Pandemi Covid-19 Bagi Tenaga Pendidik Di Lembaga Pendidikan Berbasis Pesantren Di Jawa Timur." Engagement: Jurnal Pengabdian Kepada Masyarakat 4, 
no. 1 (2020): 266-277.

Wiyoko, Tri, Megawati Megawati, Aprizan Aprizan, and Nurlev Avana. "Peningkatan Kompetensi Siswa Melalui Pembinaan Olimpiade Sains (OSN)." Warta LPM 22, no. 2 (2019): 67-75. 